Vol. 10 No. 022019

e-issn : 2622-0148, p-issn : 2087-0035

\title{
FAKTOR - FAKTOR YANG BERHUBUNGAN DENGAN PERILAKU HIDUP BERSIH DAN SEHAT (PHBS) PADA SISWA KELAS 5 SDN SUGUTAMU KOTA DEPOK
}

\author{
Factors Related To The Behavior Of Clean And Healthy Life In Grade 5 Students Of SDN SUGUTAMU DEPOK
}

\author{
Febri Hardiyanti' ${ }^{1}$, Marini Madiastuti ${ }^{2}$, Ema Hermawati ${ }^{1}$ \\ 1 Universitas Indonesia \\ 2Universitas Nasional \\ *) Febrihardiw@gmail.com
}

\begin{abstract}
The implementation of clean and healthy living behaviour in school is one of the strategic efforts to mobilize and empower the school and environment for a clean and healthy life. The school that behaves in a clean and healthy life will form healthy and intelligent students who are capital of future health development. The purpose of this research is to know the relationship between knowledge, attitudes, teacher roles and school facilities with a clean and healthy life behaviour in grade 5 students at SDN Suguguest Depok. This research is analytic with a crosssectional design. Total of 54 students was selected using the full sampling technique as a research sample. From the statistical test results, it is known that the majority of Grade 5 students at SDN Sugutamu Depok have a sufficient clean and healthy life behaviour of $59.3 \%$, a knowledge of good clean and healthy living behaviour of $68.5 \%$, attitude of life behaviour Clean and healthy good at $61.1 \%$, the role of teachers enough in supporting the behaviour of clean and healthy life is $53.7 \%$, and the school facilities to support the behaviour of a clean and healthy life is $64.8 \%$. Based on the results of analysis of bivariate test is known to have a relationship of knowledge with clean and healthy life behaviour $(P=0,003)$, attitude relationship with clean and healthy life behaviour $(P=0,043)$, relationship of teacher role with clean and healthy living behaviour $(P=0.034)$ and relationship of school facilities with a clean and healthy life behaviour $(P=0,002)$. There is a relationship between knowledge, attitudes, teacher roles and school facilities with a clean and healthy life behaviour. This research can be considered to include a clean and healthy life behaviour as a curriculum, given to students to apply it in daily life.
\end{abstract}

Keywords: Behavior, Clean and Healthy Life Behavior, Students

\section{ABSTRAK}

Penerapan Perilaku Hidup Bersih dan Sehat di sekolah adalah salah satu upaya strategis untuk menggerakkan dan memperdayakan sekolah dan lingkungannya untuk hidup bersih dan sehat. Sekolah yang berperilaku hidup bersih dan sehat akan membentuk siswa yang sehat dan cerdas yang merupakan aset dan modal pembangunan kesehatan di masa depan. Tujuan penelitian ini adalah untuk mengetahui hubungan antara pengetahuan, sikap, peran guru dan fasilitas sekolah dengan perilaku hidup bersih dan sehat pada siswa kelas 5 SDN Sugutamu Kota Depok. Penelitian ini bersifat analitik dengan desain cross sectional. Sejumlah 54 siswa dipilih dengan menggunakan teknik total sampling sebagai sampel penelitian. Dari hasil uji statistik diketahui bahwa siswa kelas 5 SDN Sugutamu Kota Depok yang memiliki perilaku hidup bersih dan sehat yang cukup sebesar 59,3\%, pengetahuan tentang perilaku hidup bersih dan sehat yang baik sebesar $68,5 \%$, sikap perilaku hidup bersih dan sehat yang baik sebesar $61,1 \%$, peran guru cukup dalam perilaku hidup bersih dan sehat sebesar $53,7 \%$, dan fasilitas sekolah cukup sebesar $64,8 \%$. Dari hasil analisa uji bivariat diketahui terdapat hubungan pengetahuan dengan perilaku hidup bersih dan sehat sebesar $(P=0,003)$, hubungan sikap dengan perilaku hidup bersih dan sehat $(P=0,043)$, hubungan peran guru dengan perilaku hidup bersih dan sehat $(P=0,034)$ dan hubungan fasilitas sekolah dengan perilaku hidup bersih dan sehat sebesar $(P=0,002)$. Terdapat hubungan antara pengetahuan, sikap, peran guru dan fasilitas sekolah dengan perilaku hidup bersih dan sehat. Penelitian ini dapat dijadikan pertimbangan untuk memasukkan kurikulum perilaku hidup bersih dan sehat dan diberikan kepada siswa untuk mengaplikasikannya dalam kehidupan sehari-hari.

Kata Kunci: Perilaku, Perilaku Hidup Bersih dan Sehat, Siswa

\section{PENDAHULUAN}

Derajat kesehatan masyarakat dapat dicapai dengan tatanan perilaku hidup bersih dan sehat. Golongan usia muda memiliki kontribusi sebagai sumber daya manusia, sebagai bahan pertimbangan untuk membuat strategi kebijakan dan sebagai penilai manfaat program serta kebijakan.
Upaya kesehatan pada golongan usia muda ditekankan pada upaya promotif dan pencegahan penyakit (WHO, 2012). Data yang dikumpulkan WHO tahun 2011-2012 dari 120.000 siswa di 28 negara di dunia, dengan rata rata responden usia 7-12 tahun, menunjukan $68,4 \%$ sudah melaksanakan perilaku 
hidup bersih dan sehat dengan baik. Negara maju menyumbang angka perilaku hidup bersih dan sehat diatas $80 \%$, negara berkembang berada dikisaran $40,6 \%$ dan negara dibawahnya dengan cakupan perilaku hidup bersih dan sehat sebesar $31,4 \%$ (WHO, 2012). Penelitian yang dilakukan oleh Berry (2012), mengungkapkan bahwa di Amerika Serikat, perilaku hidup bersih dan sehat di sekolah lebih dari $50 \%$. Dibutuhkan perilaku hidup bersih dan sehat yang baik disekolah untuk meningkatkan prestasi belajar siswa.

Penelitian tentang perilaku hidup bersih dan sehat di empat negara ASEAN (India, Indonesia, Thailand dan Myanmar) dengan responden 13.824 anak usia $9-15$ tahun, menunjukan hanya sebesar $38,4 \%$ responden yang menerapkan perilaku hidup bersih dan sehat (Peltzer \& Pengpid, 2014).

Jumlah anak di Indonesia mencapai $30 \%$ dari total penduduk di Indonesia, atau sekitar 27.381.680 anak. Terdapat lebih dari 250.000 sekolah negeri maupun swasta di Indonesia. Angka Partisipasi Sekolah (APS) usia 7-12 tahun di Indonesia adalah sebesar 98,92\% (Kemenkes RI, 2015). Banyaknya anak yang mendapatkan pendidikan dasar merupakan peluang untuk menerapkan perilaku hidup bersih dan sehat yang baik.

Di Indonesia, target perilaku hidup bersih dan sehat tahun 2019 sebesar 80\% (Kemenkes RI, 2015). Capaian perilaku hidup bersih dan sehat provinsi Jawa Barat sebesar 47,4\% (Dinkes Jawa Barat, 2015). Jumlah anak usia 7-12 tahun di Jawa Barat sebesar 4.960.823 anak, angka ini menempati Jawa Barat sebagai provinsi dengan jumlah anak usia SD/setingkat terbesar di Indonesia. Angka Partisipasi Sekolah usia 7-12 tahun di Jawa Barat juga tinggi sebesar 99,30\% (Kemenkes, 2015).

Di Kota Depok, pencapaian perilaku hidup bersih dan sehat kabupaten dan kota mengalami pasang surut, tahun 2011 capaian perilaku hidup bersih dan sehat sebesar 74,83\%, tahun 2012 mengalami penurunan menjadi 70\%, tahun 2013 capaian perilaku hidup bersih dan sehat mengalami peningkatan menjadi 74\%. Tahun 2014 capaian perilaku hidup bersih dan sehat di kota Depok sebesar $77,2 \%$, dan mengalami peningkatan pada tahun 2015 sebesar 77,5\% (Dinkes Depok, 2016).

\section{METODE}

\section{Desain, tempat dan waktu}

Penelitian ini bersifat analitik dengan desain cross sectional. Penelitian dilakukan di SDN Sugutamu Kota Depok. . Penelitian ini dilakukan dari bulan Maret-Juni.

\section{Jumlah dan cara pengambilan subjek (untuk penelitian survei) atau bahan dan alat (untuk penelitian laboratorium)} Sejumlah 54 siswa dipilih dengan menggunakan teknik total sampling sebagai sampel penelitian. Pengumpulan data dilakukan dengan menggunakan kuesioner tentang perilaku hidup bersih dan sehat, pengetahuan, sikap, peran guru dan fasilitas sekolah. Uji statistik yang digunakan adalah uji Chi Square. Dengan Confidence Interval $95 \%(a<0,05)$.

\section{HASIL}

Berdasarkan hasil uji univariat sebagian besar responden memiliki perilaku hidup bersih dan sehat yang cukup (59,3\%). Sebagian besar pengetahuan responden tentang perilaku hidup bersih dan sehat adalah baik (68,5\%). Sikap perilaku hidup bersih dan sehat yang dimiliki responden cenderung baik $(61,1 \%)$. Sebesar $64,8 \%$ responden memberikan jawaban sekolah memiliki fasilitas yang cukup dalam menunjang perilaku hidup bersih dan sehat. Analisis univariat digambarkan pada tabel 1.

Table 1. Analisis Univariat Faktor-faktor yang

Berhubungan dengan perilaku hidup bersih dan sehat pada Siswa Kelas 5 SDN Sugutamu Kota Depok

\begin{tabular}{|c|c|c|c|c|}
\hline$\overline{\text { Variabel }}$ & Kategori & $\begin{array}{l}\text { Frekuen } \\
\text { si (f) }\end{array}$ & $\begin{array}{c}\text { Prese } \\
\text { ntase } \\
(\%)\end{array}$ & $\begin{array}{c}\text { Total } \\
(\%)\end{array}$ \\
\hline \multirow{2}{*}{$\begin{array}{l}\text { Perilaku Hidup } \\
\text { Bersih dan Sehat }\end{array}$} & Baik & 22 & 40,7 & \\
\hline & Cukup & 32 & 59,3 & 100 \\
\hline \multirow[t]{2}{*}{ Pengetahuan } & Baik & 37 & 68,5 & \\
\hline & Cukup & 17 & 31,5 & 100 \\
\hline \multirow[t]{2}{*}{ Sikap } & Baik & 33 & 61,1 & \\
\hline & Cukup & 21 & 38,9 & 100 \\
\hline \multirow[t]{2}{*}{ Peran Guru } & Baik & 25 & 46,3 & \\
\hline & Cukup & 29 & 53,7 & 100 \\
\hline \multirow[t]{2}{*}{ Fasilitas Sekolah } & Baik & 19 & 35,2 & \\
\hline & Cukup & 35 & 64,8 & 100 \\
\hline
\end{tabular}

Berdasarkan hasil uji bivariat pada tabel 2 , didapatkan hubungan bermakna antara pengetahuan dengan perilaku hidup bersih dan sehat pada siswa kelas 5 SDN Sugutamu Kota Depok (Pvalue 0,003). Hasil uji selanjutnya menyatakan adanya hubungan bermakna antara sikap dengan perilaku hidup bersih dan sehat (Pvalue 0,043). Terdapat hubungan bermakna antara peran guru dengan perilaku hidup bersih dan sehat (Pvalue 0,034). Terdapat hubungan bermakna antara fasilitas sekolah dengan perilaku 
hidup bersih dan sehat (Pvalue 0,002).

Table 2. Analisis Bivariat Faktor-faktor

yang Berhubungan dengan perilaku hidup bersih dan sehat pada Siswa Kelas 5 SDN Sugutamu Kota

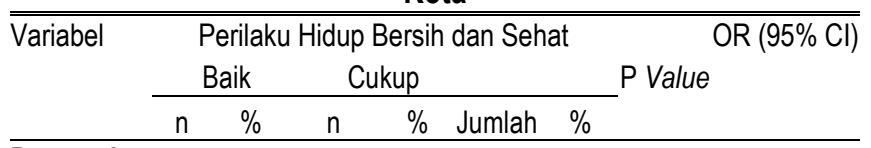

\begin{tabular}{lrrrrrrrc}
\hline $\begin{array}{l}\text { Pengetahu } \\
\text { an }\end{array}$ & & & & & & & & \\
Baik & 20 & 54,1 & 17 & 45,9 & 37 & 100 & & 8,82 \\
Cukup & 2 & 11,8 & 15 & 88,2 & 17 & 100 & 0,003 & $(1,7-44,2)$ \\
\hline Sikap & & & & & & & & \\
Baik & 17 & 51,5 & 16 & 48,5 & 33 & 100 & & 3,4 \\
Cukup & 5 & 23,8 & 16 & 76,2 & 21 & 100 & 0,043 & $(1,01-11,45)$ \\
\hline
\end{tabular}

\section{Peran Guru}

\begin{tabular}{lrccccccc} 
Baik & 14 & 56 & 11 & 44 & 25 & 100 & 3,3 \\
Cukup & 8 & 27,6 & 21 & 72,4 & 29 & 100 & 0,034 & $(1,07-10,38)$ \\
\hline \multicolumn{2}{l}{ Fasilitas Sekolah } & & & & & & & \\
Baik & 13 & 68,4 & 6 & 31,6 & 19 & 100 & & 4,25 \\
Cukup & 9 & 25,7 & 26 & 74,3 & 35 & 100 & 0,002 & $(1,83-11,82)$ \\
\hline
\end{tabular}

\section{PEMBAHASAN}

Berdasarkan hasil penelitian menunjukkan dari 54 responden penelitian, sebanyak 32 responden memiliki perilaku hidup bersih dan sehat yang cukup. Peneliti juga melakukan pengamatan perilaku terbuka (Overt Behavior) pada responden penelitian. Berdasarkan hasil pengamatan dilapangan, sebagian responden tidak melakukan perilaku hidup bersih dan sehat dengan baik, diantaranya membuang sampah masih dilapangan, tidak mencuci tangan dengan baik, dan tidak menggunakan toilet yang bersih. Banyak faktor yang dapat mempengaruhi terciptanya sebuah perilaku, diantaranya faktor predisposisi, faktor pendukung dan faktor pendorong. Perilaku juga dipengaruhi oleh pengalaman (Notoadmodjo, 2012).

Hasil penelitian menunjukkan terdapat adanya hubungan yang signifikan antara pengetahuan dan perilaku. Hubungan bermakna ini sejalan dengan penelitian Dirgahayu (2015). Pemberian informasi akan meningkatkan pengetahuan seseorang. Pengetahuan dapat menjadikan seseorang memiliki kesadaran sehingga seseorang akan berperilaku sesuai pengetahuan yang dimiliki.

Ditemukan hubungan yang bermakna antara sikap dengan perilaku hidup bersih dan sehat. Hasil penelitian ini serupa dengan penelitian yang dilakukan oleh Sondakh (2015). sikap dapat meningkatkan nilai perilaku yang berkaitan dengan kesehatan pribadi secara umum yang bersifat positif, dalam hal ini adalah perilaku hidup bersih dan sehat. Sikap merupakan reaksi yang masih tertutup dan dipengaruhi dengan pengalaman dan pengetahuan.
Dengan memiliki pengetahuan dan pengalaman tentang perilaku hidup bersih dan sehat yang positif, maka akan timbul sikap yang positif, selanjutnya akan mempengaruhi perilaku hidup bersih dan sehat yang positif.

Peran guru memiliki hubungan yang bermakna dengan perilaku hidup bersih dan sehat. Penelitian yang dilakukan Adznan (2013) juga memperlihatkan hasil yang serupa. Guru dijadikan sebagai pendidik dan role model yang ditiru oleh peserta didik. Peran guru berpengaruh dalam upaya meningkatkan perilaku peserta didik menjadi lebih baik. Peranan mereka sangat dominan dan sangat menentukan kualitas hidup anak di kemudian hari. Kualitas yang dimaksud berupa kualitas kecerdasan maupun kesehatan, Peningkatan perhatian terhadap perilaku hidup bersih dan sehat di sekolah mampu meningkatkan kualitas kesehatan anak sehingga tercipta anak usia sekolah Indonesia yang cerdas, sehat dan berprestasi.

Berdasarkan hasil penelitian, ditemukan hubungan yang bermakna antara fasilitas sekolah dengan perilaku hidup bersih dan sehat. Hasil ini serupa dengan penelitian yang dilakukan oleh Adznan (2013). Hasil penelitian ini sesuai dengan teori Lawrence Green dalam Notoadmodjo (2012) bahwa salah satu faktor yang menentukan terbentuknya perilaku hidup bersih dan sehat adalah faktor pendukung (enabling factor), yang terwujud dalam lingkungan fisik, tersedia atau tidak tersedianya fasilitas di sekolah. Masalah fasilitas sekolah berkenaan dengan keterlibatan pemerintah. Pemerintah berkewajiban meningkatkan fasilitas sekolah.

\section{KESIMPULAN}

Berdasarkan hasil analisis data univariat mengenai faktor-faktor yang berhubungan dengan Perilaku Hidup Bersih dan Sehat pada siswa kelas 5 SDN Sugutamu Kota Depok, dapat disimpulkan bahwa sebagian besar responden memiliki perilaku hidup bersih dan sehat yang cukup, memiliki pengetahuan yang baik, memiliki sikap yang baik, peran guru yang cukup, dan fasilitas yang cukup dalam menunjang perilaku hidup bersih dan sehat. Berdasarkan hasil analisis data bivariat, diketahui bahwa terdapat hubungan antara perilaku hidup bersih dan sehat dengan pengetahuan, sikap, peran guru, dan fasilitas sekolah.

\section{SARAN}

Penelitian ini dapat dijadikan gambaran perilaku hidup bersih dan sehat sekolah di wilayah kerja Puskesmas setempat. Penelitian ini dapat dijadikan pertimbangan untuk memasukkan kurikulum perilaku hidup bersih dan sehat dan diberikan kepada siswa untuk mengaplikasikannya dalam kehidupan sehari-hari. 
Vol. 10 No. 022019

e-issn : 2622-0148, p-issn : 2087-0035

UCAPAN TERIMA KASIH

Ucapan terima kasih disampaikan kepada kepala sekolah, guru, dan anak-anak SDN Sugutamu Depok.

\section{DAFTAR PUSTAKA}

Adznan. Factors related to the practice of living behavior clean and healthy in the elementary school students Kedungmundu Semarang. Semarang: University of Muhammadiyah Semarang; 2013.

Berry. Healthy School Environment and Enhanced Educational Performance, The Cleaning Industry Research Institute [Internet]. 2012 [citied 8 April 2017]. Retrieved: https://www.ciriscience.org/a_314-Healthy-SchoolEnvironment-and-Enhanced-Educational-Performance

Depok Health Office. 2016. Health Profile of Depok City 2015 [Internet]. 2015 [cited 18 April 2017]. Retrieved: http://dinkes.depok.go.id/?p=1785\#more-1785

Dirgahayu. The relationship between knowledge level and the behavior of Hidup clean and healthy students in Madrasah Ibtidaiyah Muhammadiyah Gonilan Kartasura Sukoharjo [Internet]. Faculty of Medicine of Muhammadiyah Surakarta University. 2015 [cited 23 May 2017]. Retrieved: eprints.ums.ac.id

Kemenkes RI. Health profile of Indonesia. Jakarta: Kemenkes Rl; 2015.

Kemenkes RI. Ministry of Health's Strategic Plan (Renstra) year 2015-2019. Jakarta: Kemenkes Rl; 2015.

Notoatmodjo S. Health promotion and Health Behavior, revised edition. Jakarta. Rineka Cipta; 2012.

Peltzer \& Pengpid. 'Oral and Hand Hygiene Behaviour and Risk Factors among In-School Adolescents in Four Southeast Asian Countries'. International Journal of Environmental Research and Public Health. 2014; 11: 2780-2792.

Sondakh. The relationship between the knowledge and attitudes of the clean and healthy life behavior of students at SD Inpres Sukur subdistrict of the North Minahasa regency [Internet]. Scientific journal Unsrat, vol 4 No 4. 2015 [cited 20 June 2017]. Retrieved: http://ejournal.unsrat.ac.id

West Java Provincial Health office. Strategic plan (Renstra) health Office of West Java province. Bandung: Dinkes West Java; 2015.

WHO. 'Health and Health Behaviour among Young People'. WHO Policy Series: Health Policy for Children Issue: International Report'. 2012; 11: 49-62.

WHO. Water, Sanitation and Hygiene Standards for Schools in Low-cost Settings. Geneva; 2012. 